\title{
German Jews in Jelenia Góra immediately After the End of the Second World War**
}

\section{MAREK SZAJDA}

University of Wrocław

(iD) https://orcid.org/0000-0002-1938-6762

DOI: https://doi.org/10.26774/rzz.298

$02 / 2018$

\section{ROCZNIK}

\section{ZIEM}

\section{ZACHODNICH}

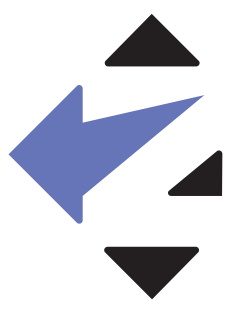

This publication is licensed under a Creative Commons Attribution-ShareAlike 4.0 International license. Some rights reserved by authors. You may use this publication in line with the license, provided that you include this license information and cite Ośrodek "Pamięć i Przyszłość" (The "Remembrance and Future" Centre) as the owner of copyrights. 
The history of the Jewish population in Poland in the period just after the Second World War is a research issue often undertaken, especially over the last two or so decades. To date, several studies dedicated to Jews in both old regions have been published, e.g. Lower and Upper Silesia ${ }^{1}$, Western Pomerania ${ }^{2}$, as well as in specific cities - Łódż $\dot{z}^{3}$ Gdańsk ${ }^{4}$, Kraków ${ }^{5}$, Wałbrzych ${ }^{6}$ or Olsztyn ${ }^{7}$. Some of these works present pioneering theses, others describe in detail the reality of Jewish committees. Apart from texts devoted to large concentrations of Jews, the general interpretation of the problem of the first five postwar years of Jewish life is also worth mentioning. Such a narrative is presented by the cycle titled $Z$ dziejów Centralnego Komitetu Żydów w Polsce (On the History of the Central Committee of Jews in Poland). Works devoted to the issues of culture, safety, so-called productivity, education, as well as political aspects of the operation of institutions ${ }^{8}$ have been released as part of this cycle. Apart from the publications mentioned above, there are also some other studies discussing the situation of the Jewish population in Poland in the period of the Polish People's Republic, focusing on, among others, the functioning of institutions ${ }^{9}$,

* This paper is a translation of the Author's paper Żydzi niemieccy w Jeleniej Górze tuż po zakończeniu II wojny światowej, published in this Issue of "Yearbook of the Polish Western Territories" on pages $187-206$

1 B. Szaynok, Ludność żydowska na Dolnym Ślqsku 1945-1950, Wrocław 2000; W. Jaworski, Żydzi na Górnym Ślasku w latach 1945-1970, Sosnowiec 2001.

2 J. Mieczkowski, Żydzi, Niemcy i Ukraińcy na Pomorzu Zachodnim w latach 1945-1956: liczba, położenie i działalność polityczna, Szczecin 1994; E. Krasucki, Historia kręci Drejdlem: z dziejów (nie tylko) szczecińskich Żydów, Łódź 2018.

3 L. Olejnik, Społeczność żydowska $w$ Łodzi latach 1945-1950. Zarys problemu, „Acta Universitatis Lodziensis. Folia Historica", Vol. 6 (1997), p. 125-147; Społeczność żydowska I niemiecka w Łodzi po 1945 roku, ed. by A. Lech, K. Radziszewska, A. Rykała, Łódź 2010.

4

G. Berendt, Żydzi na gdańskim rozdrożu (1945-1959), Gdańsk 2000

5 J. Kwiek, Żydzi, Łemkowie, Słowacy w województwie krakowskim w latach 1945-1949/50, Kraków 2002

$6 \quad$ P. Wieczorek, Żydzi w Wałbrzychu i powiecie wałbrzyskim 1945-1968, Warszawa-Wrocław 2017.

7 R. Tomkiewicz, Komitet Żydowski w Olsztynie (1946-1949), „Rocznik Ziem Zachodnich”, Vol. 1 (2017), p. 123-142.

8 A. Cała, Ochrona bezpieczeństwa fizycznego Żydów w Polsce powojennej. Komisje specjalne przy Centralnym Komitecie Żydów w Polsce, Warszawa 2014; A. Żbikowski, Sqd Społeczny przy CKŻP. Wojenne rozliczenia społeczności żydowskiej w Polsce, Warszawa 2014; A. Grabski, Centralny Komitet Żydów w Polsce (1944-1950). Historia polityczna, Warszawa 2015; H. Datner-Śpiewak, Po Zagładzie. Społeczna historia domów dziecka, szkół, kół studentów w dokumentach Centralnego Komitetu Żydów w Polsce, Warszawa 2016; P. Kendziorek, Program i praktyka produktywizacji Żydów polskich w działalności CKŻP, Warszawa 2016; A. Żółkiewska-Rejak, Zerwana przeszłość. Powojenne środowisko żydowskiej inteligencji twórczej: pomoc materialna i organizacyjna ze strony CKŻP, Warszawa 2017.

9 E. Waszkiewicz, Kongregacja Wyznania Mojżeszowego na Dolnym Ślasku na tle polityki wyznaniowej Polskiej Rzeczypospolitej Ludowej 1945-1968, Wrocław 1999; A. Grabski, Żydowski ruch kombatancki w Polsce w latach 1944-1949, Warszawa 2002; idem, Działalność komunistów wśród Żydów w Polsce. 1944-1949, Warszawa 2004; G. Berendt, Życie żydowskie w Polsce w latach 1950-1956. Z dziejów Towarzystwa Społeczno-Kulturalnego Żydów w Polsce, Gdańsk 2006; P. Pęziński, Na rozdrożu. Młodzież żydowska w PRL 1956-1968, Warszawa 2014. 
Polish and Jewish relations ${ }^{10}$, literary work ${ }^{11}$, identity ${ }^{12}$ and many other problems. There have definitely been fewer studies focusing on the functioning of the Jewish community at a local or regional level. Only in the light of a few articles does one have a micro vision of Jewish life, acquainting oneself with the postwar reality through the prism of Tarnów, Swidnica ${ }^{13}$ or other smaller town communities, in which Jewish institutions appeared once again after 1945. Even less information may be found on the community of German Jews that also functioned for at least a few years after the end of the war in the Western and Northern Territories ${ }^{14}$. This text takes a look at one of the many cities of Lower Silesia, postwar Jewish estate. The article presents Jelenia Góra in the years 1945-1947, within the limits of which one of the first Jewish committees, exceptional due to the presence and activity of German Jews, was established. By means of the example of Jelenia Góra, the author aims to present the problems of this community, as well as examples of several persons and events crucial to understanding the context of Jewish life in the city. He considers questions relating to the status of the committee and its members, as well as real opportunities of staying on the territories granted to Poland.

\section{German Jews in Jelenia Góra before 1945}

The modern history of Jews in Jelenia Góra (de. Hirschberg im Schlesien) is connected with the State of Prussia. In 1812, after the implementation of the edict introducing the equality of Jewish population ${ }^{15}$, many people decided to settle in Silesia, also in the vicinity of the Karkonosze ${ }^{16}$. The growing community in the city in the second

10 K. Kersten, Polacy, Żydzi, komunizm. Anatomia półprawd 1939-68, Warszawa 1992; B. Szaynok, Z historiq i Moskwq w tle. Polska a Izrael 1944-1968, Warszawa-Wrocław 2007; Społeczność żydowska w PRL przed kampaniq antysemickq lat 1967-1968 i po niej, red. G. Berendt, Warszawa 2009.

11 Nusech Pojln. Studia z dziejów kultury jidysz w powojennej Polsce, red. M. Ruta, Kraków-Budapeszt 2008; M. Ruta, Bez Żydów? Literatura jidysz w PRL o Zagładzie, Polsce i komunizmie, Kraków-Budapeszt 2012.

12 M. Melchior, Społeczna tożsamość jednostki w świetle wywiadów z Polakami pochodzenia żydowskiego urodzonymi w latach 1944-1955, Warszawa 1990; idem, Zagłada a tożsamość. Polscy Żydzi ocaleni "na aryjskich papierach". Analiza doświadczenia biograficznego, Warszawa 2004; M. Starnawski, Socjalizacja i tożsamość żydowska w Polsce powojennej: narracje emigrantów z pokolenia marca '68, Wrocław 2016.

13 M. Wolny, Ludność żydowska w Świdnicy w latach 1945-1970, „Rocznik Świdnicki”, 2003, p. 128-157.

14 Among the most interesting German language publications, see: H. Hirsch, Gehen oder bleiben? Juden in Pommern und Niederschlesien 1945-1955, Göttingen 2011; M. Ruchniewicz, K. Ruchniewicz, Das neue jüdische Leben in Polen - Juden in Niederschlesien nach 1945, [in:] Jüdishes Leben zwischen Ost und West. Neue Beiträge zur jüdischen Geschichte in Schlesien, ed. by A. Herzig, K. Ruchniewicz, A. Brämer Göttingen 2014, p. 473-502; K. Friedla, Juden in Breslau/Wrocław 1933-1949: Überlebensstrategien, Selbstbehauptung und Verfolgungserfahrungen, Köln [et al.] 2015.

15 Under The Emancipation Edict Jews obtained citizenship rights in Prussia and the status of Einlander. See: M. Brenner, German-Jewish history in modern times. Vol. 2: Emancipation and acculturation: 1780-1871, New York 1997, p. 24-27.

16 It was the consequence of the right to free choice of place of settlement; for more about the exceptional dynamics of Jewish community development, among others in Jelenia Góra, see: L. Ziątkowski, Między niemożliwym a koniecznym. Reformy państwa pruskiego w końcu XVIII i na poczq̨tku XIX wieku a proces równouprawnienia Żydów ze szczególnym uwzględnieniem sytuacji na Ślasku, Wrocław 2007, p. 136-138. 
half of the $19^{\text {th }}$ century numbered almost 450 members ${ }^{17}$. A little earlier, in 1846 , a newly built synagogue was ceremonially opened (Mikołaj Kopernik Street today), and blessed by rabbi Abraham Geiger from Wrocław. In the following century, Jews were a slightly smaller group. In 1933, only 240 persons belonged to the Jewish Community, and one year later -182 persons ${ }^{18}$. Successively, the legislation introduced in the Third Reich against Jews, influenced migrations and a slow decline also in the community of Jelenia Góra. Anti-Semitic excesses were a separate issue, among others the murder of five Jews from Jelenia Góra ${ }^{19}$ in July 1934 or the devastation of a synagogue during the Kristallnacht. In this context, an interesting source of knowledge on Jewish history in the city is the 1938 study by Heim Mothes ${ }^{20}$. In the typescript of his work he included not only the historical outline of the community but, most of all, its situation at that time. He specified the size of the group and described individual members of the community. Thanks to this work, it may be determined that on the threshold of the Extermination in Jelenia Góra there were 144 Jews $^{21}$ : 68 women and 76 men. Preliminary analysis of jobs and house or flat localisations on a city map indicates that affluent persons constituted the majority of the group. Definitely, most people came from Silesia, including Jelenia Góra itself. There were 35 tradesmen who dominated among the different professions. In Jelenia Góra, there were also three factory owners and barristers, a rabbi, a doctor, a dentist, a craftsman, a shop assistant as well as some representatives of several different professions. The majority of them identified themselves as Jews. Some, but these are separate examples, described themselves as Catholic, Evangelic or nondenominational. The author of the study did not forget to mention persons called "Mischling"22 according to German law of that time, who apparently numbered 16 in

17 M. Borkowski, A. Kirmiel, T. Włodarczyk, Śladami Żydów: Dolny Ślask, Opolszczyzna, Ziemia Lubuska, Warszawa 2008, p. 28-29. In this period of time, there was a constant population growth in the city. In 1872 Jelenia Góra was inhabited by 11776 people, and in 1913 as many as 21244 persons. Zbigniew Kwaśny specified the number of Jews ("Moses worshippers") in the city in 1885 - 396 people, which was to constitute about 2.5 per cent of the city population, see: Z. Kwaśny, Na nowej drodze rozwoju (do I wojny światowej), [in:] Jelenia Góra. Zarys rozwoju miasta, Wrocław 1989, p. 132-133.

18 It is even more significant that in this very period there was a visible increase in the number of in habitants, caused by, among others, territorial changes. In 1922 there were 22381 people, and in 1939 as many as 32764 persons. See: ibidem, p. 175.

19 This event was described for example by Willy Cohn in his diary dated the 5th of July 1934: "In the town of Hirschberg five Jews were shot, among others businessman Charig and barrister Förster, the son-in-law of Siegmund Cohn, the legal adviser. I can't imagine that" and further on the 9th of July 1934: "[...] I've also heard another version of events - that it was the action of rebels who attacked too soon. Supposedly, they wanted to take hostages and confiscate Jewish properties. It is not known, obviously, what is true but nothing will bring life back to the poor people", see: W. Cohn, Żadnego prawa - nigdzie. Dziennik z Breslau 1933-1941. Wybrane fragmenty, ed. by N. Conrads, Wrocław 2010, p. 63-64.

20 The State Archives in Wrocław, Jelenia Góra Branch (Polish abbreviation: APJG), Library, ref. no. 205 H. Mothes, Die Juden in Stadt und Kreis Hirschberg i. Rsgb, typescript, Hirschberg 1938, n.pag. It is hard to define who ordered the preparation of this study. Certainly, it is scrupulously completed. In the source material, the author specifies the archives and other documents, including those of administrative character, as well as conversations with officials. It might be it is the result of the political zeal of its creator.

21 Ibidem.

22 In German - mixed-blood (in lay terms: hybrid, mongrel or half-breed - translator's note); the term refers to Germans related to Jewish people, it was introduced in the Nuremberg Laws in the Third Reich in 1935. 
Jelenia Góra. In his work, Mothes also placed exact statistics applying to Jewish populations in rural districts. He included 77 people in this group and 14 others defined as having mix-blood origin.

Essential knowledge about the atmosphere of the day and the Jewish community in the city was delivered years ago by Jane Lester in an interview on oral history given to USC Shoah Foundation History Archive workers ${ }^{23}$. In 1938, the interviewee was working in Jelenia Góra as teacher to Annemarie Sachs. The girl, born in 1924, was daughter of Martin Sachs (born in 1882), the owner of one of the city's textile factories. In the opinion of Lester, he was a prosperous entrepreneur. His beautiful and well-furnished flat, as well as Sachs' business trips might have confirmed that view. According to the teacher, he did not identify himself with Jewishness; on the contrary, he was assimilated, belonged to the Lutheran Church and his wife was a Catholic. Despite these very facts, Lester mentions his employer's three-week stay in a concentration camp because of his origin and political remarks he made. A witness related what Sachs had said: "I don't know what Hitler has against me. I have ever always kept away from politics. I am strictly unpolitical" ${ }^{\prime 2}$. Again in 1938, the entrepreneur was said to have received an offer from Brazil to transfer the majority of his capital there and begin production in the textile industry. Lester met Sachs for the last time in August $1939^{25}$ in Hamburg.

Not all Jews from Jelenia Góra had the good fortune to flee from Germany before the Extermination. The vast majority died during the Second World War in death camps. Toni Głogowski, the wife of Izydor, a member of Jewish Community board, departed from Jelenia Góra and went to Berlin, from where in October 1942 she was taken by a transport destined for the camp in Theresienstadt in the territory of modern-day Czech Republic. There she died. It might be that her husband met a similar fate. Another member of the Community board, Simon Sachs, died in Treblinka. Jean Hirschfeld lost his life after his departure to the Netherlands, and Israel Apel in Sachsenhausen. In Teresienstadt, other Jews from Jelenia Góra were also murdered - Johan Adler and a married couple Anna and Herman Cohn. Herman Feder died in Dachau, other members of his family - in the camp at Majdanek near Lublin. The fact is that a significant part of Jewish community from prewar Jelenia Góra died during the Extermination ${ }^{26}$. The survivors were in hiding during the war in not entirely

23 USC Shoah Foundation - Visual History Archive, ref. no 11882, The oral history interview with Jane Lester from 20.03.1996 (interviewer Esther Finder).

24 Ibidem.

25 Ibidem. According to the account of Jane Lester, in August 1939, Martin Sachs met her for the last time in Hamburg. Their conversation referred, among other things, to the possible outbreak of war and the security of the Jewish population.

26 The stories cited after: The Memorial Book of the Federal Archives for the Victims of the Persecution of Jews in Germany (1933-1945), online: https://www.bundesarchiv.de/gedenkbuch/index.html.en (access: 12.06.2018); The Central Database Of Shoah Victims' Names, online: https://yvng.yadvashem.org/ (access: 12.06.2018) 
known circumstances ${ }^{27}$. Some of them, according to German legislation, were recognised as "Mischling", e.g. Annemarie Schermann"28, described by Helga Hirsch. And yet some others survived the Extermination period in concentration camps, including KL Gross-Rosen branches. And it is this diversified group that created the first structures of postwar Jewish life in the city in 1945.

\section{Jews in Gross-Rosen camp branches}

During the Second World War in Jelenia Góra, as in many other cities in Silesia, Gross-Rosen concentration camp branch was in operation. Initially, as early as in 1940, in the city, a labour camp for Jews was established - the so-called Schmelt Organisation ${ }^{29}$, Special Plenipotentiary of SS Reichsführer for Foreign Nationalities Employment Issues in Upper Silesia. And on the basis of this structure in March 1944 KL Gross-Rosen branch - AL Hirschberg ${ }^{30}$ appeared. A year earlier, an Arbeitskommando was created that functioned during operations conducted at Zellwolle factory. Prisoners came from different European countries, among others from Poland, Hungary, the Netherlands and France ${ }^{31}$. Their work was connected with wood processing, a fact that a prisoner Marian Wojciechowski ${ }^{32}$, a carpenter by trade, discussed in detail in his report. Similar camp branches existed at manufacturing facilities in neighbouring towns, e.g. in Bad Warmbrunn (Cieplice Śląskie, currently part of Jelenia Góra) and Zillerthal-Ermannsdorf (Mysłakowice ${ }^{33}$ ). Along with the withdrawal of the German army due to the offensive of the Red Army in January 1945, many prisoners from concentration camps were evacuated to units deep into the country. At that time, during debilitating death marches, some prisoners ended up temporarily in Jelenia Góra camp. For example, Eva Gross spent several weeks

27 According to the register of people having Jewish origin, compiled on 2nd August 1945 in Jelenia Góra and area (in the territory of present-day Jelenia Góra poviat, among others in such localities as: Szklarska Poręba, Kowary, Miedzianka, Łomnica, Wojanów, Przesieka, Karpacz, Janowice Wielkie, etc.) 83 persons were noted down, in individual cases from Hungary, France, Austria, England. German Jews constituted the vast majority of the group, including persons called Mischling. The State Archives in Wrocław, The Voivodeship Office in Wrocław, Sprawy narodowości żydowskiej (Jewish Nationality Issues), ref. no. VI/269, Lista osób żydowskiego pochodzenia (The list of persons of Jewish origin), 02.08.1945, cards 19-22.

28 H. Hirsch, op .cit., p. 34

29 A. Kobielec, Więźniowie Żydzi w KL Gross-Rosen. Stan badań, Wałbrzych 1993, p. 9; see more: A. Konieczny, The "Schmelt organisation" in Silesia, [in:] Jews in Silesia, ed. by M. Wodziński, J. Spyra, Kraków 2001, p. 173-179.

30 A. Kobielec, Filie obozu koncentracyjnego Gross-Rosen. Informator, Wałbrzych 2008, p. 41.

31 M. Sadowski, $Z$ badań nad więźniami żydowskimi wyzwolonymi $w$ filiach obozu koncentracyjnego Gross-Rosen, "Studia nad Faszyzmem i Zbrodniami Hitlerowskimi", Vol. 16 (1993), p. 260. On the basis of the register of former prisoners from different camp branches, the author lists 13 countries from which liberated Jews had come from.

32 USC Shoah Foundation - Visual History Archive, ref. no. 43790, Oral history interview with Hersi Berkowitz from 28.05.1998 (interviewer Lorrie Fein). 
there before she was directed to another unit in the Czech Republic ${ }^{34}$. Analogically, Martin Kohn, who finally went to the branch in Dornhau ${ }^{35}$ (Kolce, presently in the municipality of Głuszyca in Wałbrzych poviat ${ }^{36}$. In Jelenia Góra at the turn of February and March 1945, camp evacuation was also undertaken. Some prisoners were directed to e.g. KL Buchenwald. A group of 905 people arrived there on $7^{\text {th }}$ March. Prisoners from other evacuated branches were part of this group too, among others from Bolków ${ }^{37}$. Some people survived till the end of the war in Jelenia Góra Basin. The unit in Bad Warmbrunn ${ }^{38}$ was one of several dozens of non-evacuated undercamps. In an oral history interview, Michael Kishel mentioned his astonishment, when on the morning of the $10^{\text {th }}$ May there were no German soldiers guarding camp prisoners and soon after he met representatives of the Red Army ${ }^{39}$. On the other hand, postwar documentation gathered for the needs of investigation against German crimes revealed that in May 1945 seventy Jewish prisoners from Kowary area were counted as tuberculosis patients in Bukowiec hospital. ${ }^{40}$. The state of health of these ill and exhausted people was serious enough for them to spend several subsequent weeks in the institution. Similar medical institutions accepted a great number of Jewish people from branches concentrated around the Riese complex in the Sowie Mountains, e.g. in Głuszyca. The presence of those former prisoners is also confirmed by some other documents. The picture of forced labourers, including Jews, photographing themselves at one of the vantage points at the edge of the town at the no longer existing Helicon ${ }^{41}$ is symbolic.

\section{German Jews Committee}

The fact that Jewish people - former concentration camp prisoners - were living in the area of Jelenia Góra is crucial in the context of the establishment of the first

34 USC Shoah Foundation - Visual History Archive, ref. no. 10030, Oral history interview with Eva Gross from 20.02.1998 (interviewer Bernice Krantz).

35 USC Shoah Foundation - Visual History Archive, ref. no. 888, Oral history interview with Martin Kohn from 8.02.1995 (interviewer Dana Schwartz).

36 It's an administrative unit in Poland, the equivalent of a county or district in other countries (translator's note).

37 A. Konieczny, Ewakuacja obozu koncentracyjnego Gross-Rosen w 1945 r., „Studia nad Faszyzmem i Zbrodniami Hitlerowskimi", Vol. 2 (1975), p. 181.

38 Ibidem, p. 186

39 USC Shoah Foundation - Visual History Archive, ref. no. 6526, Oral history interview with Michael Kishel from 6.09.1995 (interviewer Naomi Rappaport).

40 AIPN (Institute of National Remembrance Archives) in Wrocław, ref. no. 476/40, Dokumenty Okregowej Komisji Badania Zbrodni Hitlerowskich Delegatury w Jeleniej Górze (Documents of District Commission For the Investigation of Nazi Crimes, Delegation in Jelenia Góra), A Letter of Wojciech Tabaka from 27.03.1972, card 9.

41 The Ghetto Fighters' Kibbutz Archives, catalogue number: 10237, ref. no. of a photograph 00806p. Helicon - a neo-classicist building modelled after an Classical temple, dedicated to Prussian King Frederick II (or Frederick The Great), erected on Siodło Hill. 
postwar institutions of Jewish life. Similar to the case of Dzierżoniów and Bielawa, where liberated prisoners established a committee of former prisoners as early as on $8^{\text {th }}$ May 1945 that was later transformed into the Jewish Committee ${ }^{42}$, also in the capital of the Karkonosze Mountains an analogical initiative was taken, though belatedly. In a paper dated $6^{\text {th }}$ July 1945, the Polish Republic Government Representative for District number 29 was informed about the "Local Jewish Committee" coming into existence. It had been established to "bring help and assistance to local Jews, or those returning to the country ${ }^{\prime 43}$. More details were included in another letter directed once again to Jelenia Góra starost (Polish term close to Chief Executive or County Head - translator's note), Wojciech Tabaka. Three people responsible for the functioning of institutions were mentioned there - Dr William Basser, Dr Eryk Popper ${ }^{44}$ and Horst Hirschfeld ${ }^{45}$. The following information was given: "The Committee is to take over and represent the interests of all Jews and especially Jewish inhabitants as well as former Concentration Camps prisoners living in Jelenia Góra poviat and city"46.

In my opinion, the syntax of the tex $\mathrm{t}^{47}$ quoted above and the mentioned individuals demonstrate the German character of the committee and its staff composition. In a document from the beginning of September 1945 addressed to Stanisław Piaskowski, Polish Republic Government Delegate for Lower Silesia District, the starost Wojciech Tabaka already mentioned that the Jewish organisation had attracted more than 200 people, that it had come into being and that it had been given documents proving its registration. German Jews as well as the French Jew Julian Wasser ${ }^{48}$ mentioned by the sender belonged to the organisation. In the register conducted earlier, possibly by the

42 M. Szajda, Poczqtki instytucjonalnego życia żydowskiego na Dolnym Ślqsku od maja do sierpnia 1945 roku, [in:] Koniec wojny na Ślasku. Rok 1945. Studia i materiały, ed. by K. Jasiak, K. Kawalec, P. Stanek. WrocławOpole-Warszawa 2008, p. 170-171.

43 The State Archives in Wroclaw, The Voivodeship Office in Wrocław, Sprawy narodowości żydowskiej [Jewish Nationality Issues], ref. no. VI/269, Pismo Lokalnego Komitetu żydowskiego w Jeleniej Górze do ob. wojewody w Legnicy (The Letter of Local Jewish Committee in Jelenia Góra to the Viovodship Governor in Legnica), 06.08.1945, card 7.

44 In an already mentioned prewar Jewish population register, Erich Popper appears at the address of Langstrasse 6 (Długa Street at present, in the centre of the city). Other data are also given: the date and place of birth - 02.10.1886, Poznan, and the number of children - 2; see: H. Mothes, op. cit., n.pag.

45 He might have been a member of the Hirschfeld family mentioned in a prewar register, inhabiting Kaiser Friedrichstrasse 11 (Jan Matejko Street nowadays), see: ibidem.

46 The State Archives in Wrocław, The Voivodeship Office in Wrocław, Sprawy narodowości żydowskiej (Jewish Nationality Issues), ref. no. VI/269, Pismo Lokalnego Komitetu żydowskiego w Jeleniej Górze do ob. wojewody w Legnicy (The Letter of Local Jewish Committee in Jelenia Góra to the Viovodship Governor in Legnica), 06.07.1945, card 7.

47 In Polish (translator's note).

48 Ibidem, Pismo Pełnomocnika Rządu RP na obwód nr 29 Jelenia Góra do Pełnomocnika Rządu RP na Okreg Administracyjny Dolnego Ślasska w Legnicy (The Letter of Polish Republic Government Delegate for the Circuit No 29 Jelenia Góra to Polish Republic Government Delegate for Administrative District of Lower Silesia in Legnica), 03.09.1945, card 15. 
committee members themselves, 83 people ${ }^{49}$ inhabiting the territory of the whole poviat, including 43 people in Jelenia Góra itself, were found on the list of those registered dated $2^{\text {nd }}$ August 1945. German Jews constituted the biggest group, though they were not the only ones. There are also separate, individual examples of people from Hungary, England, Austria and France. The list is rather detailed; for example, it contains information about when a specific person is present in the territory of a town. Prisoners transported to the area of Jelenia Góra Basin during the war are probably about the half of the group. The description accompanying their surnames includes an exact year or sometimes the month of their arrival; in some cases even the name of the camp they had come from. Jewish inhabitants of the poviat who declared a long-term stay reaching back to the 1920s and the 1930s belonged to the remaining part of the group. In fact, some of these are found on the already mentioned lists of Jewish people from 1938 though at a different address. A good example is Erich Popper, a barrister, one of the creators of the Jewish committee, born in Poznań in 1886 and a resident of Jelenia Góra from 1919. It is difficult to prove how those tens of people successfully hid their provenance and got away from danger or avoided the fate of the majority of Jews from Hirschberg ${ }^{50}$. The committee of German Jews established in July was not the only institution of its kind. A similar organisation was formed in Wrocław. As early as August 1945, Moses Linkowski, the Voivodeship Jewish Committee delegate, met the committee founders in old Breslau. He related:

[...] they informed me that in Wrocław there were 2000 Jews at present, including 200 Polish Jews who in their opinion were temporarily living in Wrocław; the rest of the 1800 local Jews were composed in half of true Jews and in half of so-called half-Jews of the first and second generation. The activity in Wrocław is limited to providing support for local Jews and assisting Jews returning from camps through Wrocław ${ }^{51}$.

Undoubtedly, in other cities similar committees might also have come into existence, especially in those places where German Jews were staying, at least in Kłodzko or Wałbrzych. However, there is no source confirmation of this thesis.

In this context, it is worth paying attention to the problem of the demography of this specific group. In his work devoted to Jewish people in Lower Silesia, Szyja Bronsztejn gives the number of 135 persons in the territory of the whole Lower Silesia

49 Ibidem, Lista osób żydowskiego pochodzenia (The list of people of Jewish origin), 02.08.1945, cards 19-22. Document does not contain the first page. In some studies different numbers are given, e.g. 79 people, see: H. Hirsch, op. cit., p. 33.

50 For example in reference to Berlin, M. Brenner mentions 1416 Jews who survived in hiding and were in the capital of Germany after the war, see: M. Brenner, Nach dem Holocaust. Juden in deutschland 1945-1950, München 1995, p. 63.

51 The Archives of the Department of Jewish Studies at Wrocław University, Akta Wojewódzkiego Komitetu Żydowskiego na Dolny Śląsk (The Acts of the Jewish Committee for Lower Silesia), ref. no. 1, Protokoły i sprawozdania z działalności Wojewódzkiego Komitetu Żydowskiego w Rychbachu (Dzierżoniowie) 1945 (Minutes and reports of the Voivodeship Jewish Committee activities in Rychbach (Dzierżoniów) 1945), The report of the member of the Voivodeship Committee - M. Linkowski on the departure to Wrocław, Rychbach 10.09.1945, n.pag 
Voivodeship that are described as Jew-autochthones, implicitly of German origin ${ }^{52}$. The same number is referred to by Leszek Ziątkowski ${ }^{53}$. In a slightly earlier work, Arnold Goldsztejn mentions 2000 Jews liberated from camps, including 200 of Polish origin, who were said to be staying in Wrocław in $1945^{54}$. He probably cites the data after Linkowski (quoted earlier). On the other hand, Bożena Szaynok, referring to the documents of the Central Committee of Jews in Poland (CCJP, in Polish CKŻP), reports the number of 400 German Jews registered by the Wrocław committee ${ }^{55}$. Yet another perspective is presented by Andrzej Rykała, who describes the issue of Jewish groupings in the territory of Poland in the period after 1945, but does not mention any representatives of the Jewish community other than those from Poland ${ }^{56}$.

Presenting so different numbers were caused by defective documentation or referring to only partially known data. Detailed information on the Jewish population depends most of all on the period being discussed. The dynamics of migrations or simply social changes among Jewish people were exceptionally high, especially in the years 1945-1946. In the case of the Jelenia Góra, it is worth looking at information included in the discussed documents. The list from the beginning of August 1945 contains data on more than 80 people $^{57}$ and yet one month later the starost, citing a talk with the committee's representatives, mentions more than 200 registered person ${ }^{58}$. It is not known whether among those registered there were Jews from different countries, liberated camp prisoners or most of all German Jews ${ }^{59}$. Moreover only adult persons were included. Neither is it known whether it included people returning to their hometowns. Yet another problem to which the author plans to return is the question of the "Mischling". Certainly those people might also have

52 S. Bronsztejn, Z dziejów ludności żydowskiej na Dolnym Ślq̨sku po II wojnie światowej, Wrocław 1993, p. 8. This number refers to the second half of the year 1947 and the register conducted by the Socio-Political Department of the Voivodeship Office in Wrocław. It does not correlate with the situation from two years previously. The author does not mention German Jews in his earlier works on the subject either, see: S. Bronsztejn, Uwagi o ludnosci żydowskiej na Dolnym Ślaskku w pierwszych latach po wyzwoleniu, "The Bulletin of the Jewish Historical Institute", No. 75 (1970), p. 31-74.

53 L. Ziątkowski, Dzieje Żydów we Wrocławiu, p. 113.

54 A. Goldsztejn, Powstanie skupiska ludności żydowskiej na Dolnym Śląsku w latach 1945-1947, „Śląski Kwartalnik Historyczny Sobótka", Vol. XXII (1967), no. 1-2, p. 193.

55 B. Szaynok, Ludność żydowska..., 28.

56 A. Rykała, Rozmieszczenie Żydów w Polsce po drugiej wojnie światowej (1945-1950), „Rocznik Łódzki", Vol. 48 (2001), p. 149-174; A. Rykała, M. Kulesza, W kwestii skupisk ludności żydowskiej na Ślqsku w pierwszych latach po II wojnie światowej, „Studia Śląskie”, vol. 6 (2002), p. 235-254.

57 The State Archives in Wrocław, The Voivodeship Office in Wrocław, Sprawy narodowości żydowskiej (Jewish Nationality Issues), ref. no. VI/269, Lista osób żydowskiego pochodzenia (The list of people of Jewish origin), 02.08.1945, cards 19-22.

58 Ibidem, Pismo Pełnomocnika Rządu RP na obwód nr 29 Jelenia Góra do Pełnomocnika Rządu RP na Okręg Administracyjny Dolnego Śląska w Legnicy (The Letter of Polish Republic Government Delegate for the Circuit No. 29 Jelenia Góra to Polish Republic Government Delegate for Administrative District of Lower Silesia in Legnica), 03.09.1945, card 15.

59 The list consist of data: name, last name, date of birth, place of birth, place of residence (since when) citizenship. 
registered themselves in newly established organisations though it is difficult to define the scale of these activities.

Katharina Friedla gave a partial answer to the above doubts. In her work dedicated to Wrocław Jews, the researcher determined their number to be about 1600-1800 people right after the end of the war. At the turn of the years 1945 and 1946, the community amounted to just under 1000 people. On the basis of these calculations, it has to be admitted that German Jews constituted a larger group than has thought over the years ${ }^{60}$. It may be that more detailed research will reveal more precise numbers applying to other locations and German Jews staying there. The data sent to the CCJP for August indicate that 150 people were registered with committee in Jelenia Góra ${ }^{61}$. In the opinion of the author, this number refers - in the vast majority of cases - just to "Jews-autochthones".

The German Jews committee established in July 1945 in Jelenia Góra functioned in this form for quite a short period of time. As early as $23^{\text {rd }}$ August a letter informing the authorities about the establishment of the Jewish Committee, a branch of the CCJP, together with a request for permission to conduct registration "within the city of Jelenia Góra and in its area"62 was received by the starost. The seal at the bottom of the document shows that it was created by the representatives of the Jewish Committee in Jelenia Góra located at 27 Gotschdorferstrasse (currently Spółdzielcza Street), that is an institution already established by German Jews (sic!). The starost Wojciech Tabaka in his letter dated more than one week later written to the voivode, mentioned his doubts concerning two different groups of Jews who had wanted to register Jewish people and had presented themselves as the community representation ${ }^{63}$.

The matter is finally explained by the documentation of the Voivodeship Jewish Committee (VJC) in Dzierżoniów, the representatives of which visited Legnica and Jelenia Góra at the beginning of August - the latter in connection with the information about the existence of the German Jews committee. In the report on this tour, there was a statement that the VJC president Jakub Egit "had created a Polish Jews Committee in this place and two representatives of the existing Committee had become part

60 M. Sadowski, Deportacje niemieckich Żydów z Wrocławia do KZ-Theresienstadt w styczniu $i$ kwietniu 1944 r., "Studia nad Faszyzmem i Zbrodniami Hitlerowskimi", vol. 18 (1995), p. 264. The author, describing the last deportations of Jews from Wrocław, mentions only a group of people hiding and/or living in mixed marriages. Though he does not mention the number, he writes that in Wrocław "the once thriving community, with its roots in the Middle Ages, has been almost totally annihilated", the statement suggests that there were a residual number of Jews remaining in the city. B. Szaynok and Sz. Bronsztejn cited above also mentioned a small community.

61 B. Szaynok, Ludność żydowska..., p. 26.

62 The State Archives in Wrocław, the Voivodeship Office in Wrocław, Sprawy narodowości żydowskiej (Jewish Nationality Issues), ref. no. VI/269, Pismo Centralnego Komitetu Żydów Polskich w Warszawie do Starostwa Powiatowego Wydziału Propagandy w Jeleniej Górze (The Letter to the Central Committee of Polish Jews in Warsaw to the District Office, the Department of Propaganda in Jelenia Góra), card 23.

63 Ibidem, Pismo Pełnomocnika Rządu RP na obwód nr 29 Jelenia Góra do Pełnomocnika Rządu RP na Okreg Administracyjny Dolnego Śląska w Legnicy (The Letter of Polish Republic Government Delegate for the District 29 Jelenia Góra to the Polish Republic Government Delegate for the Administrative District of Lower Silesia in Legnica), 03.09.1945, card 15. 
of the VJC and had committed to cooperate in all fields" ${ }^{\prime \prime 4}$ (translation - M. Świtała). In further extracts, settlement possibilities were discussed, which a delegation of Jews from Przemyśl was to be responsible for - those who had been interested in migration to that area. Thus, the registration conducted at the end of August was organised by the committee cooperating with the VJC, and therefore also with the CCJP. At the same time, it was one of the first structures of Jewish people representation in Lower Silesia. Formally, the committee brought together Polish Jews but in reference to the period of the day this statement may be considered purely theoretical as German Jews constituted the majority of those registered. This situation also caused another problem. The committee aimed at helping Jews who had survived the Extermination. As the president of the CCJP, Emil Sommerstein declared:

The issue of camp prisoners is one of the most important problems. It needs to be solved so that assistance is really provided. At minister [of Public Administration - author's note] Ochab's the issue has been presented in such a manner that Jewish camp prisoners are in an especially difficult situation, much worse than Polish camp prisoners as the latter return to their families and homes, while Jewish prisoners have nobody and nothing to return to; they must be supported by Jewish Committees for some time ${ }^{65}$.

The issue of nationality and Jewish identity turned out to be an central problem, with serious consequences for "Jew-autochthones", who were perceived mainly through the Germaness. This problem was almost imperceptible both to activists in Warsaw, representing Polish Jews in the strict sense and to the government administration coping with the problem in practice.

\section{Jews or Germans? - legal or social problem?}

Apart from the German Jews committee in Jelenia Góra, there was a similar organisation in Wrocław, embracing a much bigger community. It is this very structure that temporarily, in June 1945, competed with the committee in Dzierżoniów for superiority over other committees. In fact, it was a dispute over the following problem - which committee was to be known as the voivodeship committee and function as the CCJP representation. Although the head office representatives visiting Lower Silesia accepted the supreme authority of Dzierżoniów activists, they did not want to deprive German Jews from old Breslau of their rights as they had also founded a committee and desired to protect all survivors. A more significant issue of disagreement, against the background of the discussed debate, was the problem of the authorities' attitude towards German Jews and their status. In one of the letters addressed to the voivode, the authors - "autochthones" - reminded him of a promise

64 Ibidem, Wojewódzki Komitet Żydowski (The Voivodeship Jewish Community), ref. no. 1, The Minutes of the WKŻ Presidium meeting, 08.08.1945, card 17.

65 The Archives of Jewish Historical Institute, the Central Committee of Jews in Poland, Presidium and secretary's office, ref. no. 303/1/7, Presidium. Organisational Acts, Minutes from the CCJP Presidium meeting, 04.06.1945, card 70 . 
given by the CCJP representatives, namely the declaration made during the meeting on $27^{\text {th }}$ June 1945 :

[...] we were promised the equality of German and Polish Jews in every field and in all respects under the Ministerial act. According to the information from the Central Jewish Committee in Warsaw, this act has entered into force and the Voivodeship was informed about this very fact. The authorities in the area of Wrocław do not want to grant us the rights that we are entitled to, on the basis of the above act, assuming that they have been informed about this matter ${ }^{66}$.

Thus, they were officially claiming the rights they were entitled to as either victims of the Third Reich or simply members of Jewish community. Similar problems appeared in other territories inhabited by groups of German Jews. The circular of the Ministry of Public Administration, separated this group from the whole of German people, among others on the basis of a temporary certificate authorising them to stay in Poland ${ }^{67}$. Subsequently, individual people could obtain the right to permanent settlement, among other things through a verification process. Thanks to this fact, what Grzegorz Berendt underlines, that German Jews did not hide their identity, because they hoped for a better income and benefits, at least of material character unlike the remaining German citizens. Unfortunately sometimes, as in Słupsk, the community of "Jew-autochthones" faced hostility, for example in the form of insults on the part of Poles coming to this city ${ }^{68}$.

The community of German Jews found themselves in a similar situation in the capital of the Karkonosze Mountains. In a letter from August 1945, starost Tabaka asked the voivode about the status of this group, indicating specific problems he was facing:

Due to the establishment of a Jewish Committee in the territory of Jelenia Góra poviat, I am asking for an explanation about the way Jews of foreign nationality should be treated, such as Jews possessing French, Czech, German, and Dutch citizenship, etc. In view of the fact that some Jews, especially those of German origin, have unclear documents or do not possess them at all, I am asking for an explanation as to what to do in specific cases and how to treat those people. Jews of Polish citizenship are treated as Poles but as for foreign Jews I do not have any official instructions ${ }^{69}$.

66 The State Archives in Wrocław, the Voivodeship Office in Wrocław, Sprawy narodowości żydowskiej (Jewish Nationality Issues), ref. no. VI/269, Pismo Komitetu Żydowskiego we Wrocławiu do Pełnomocnika Rządu na okręg Administracyjny Dolnego Śląska w Legnicy dot. ustalenia punktu prawnego Żydów dawnych obywateli niemieckich w województwie Dolnego Ślaska (Letter from the Jewish Committee in Wrocław to the Government Delegate for the Administrative District of Lower Silesia in Legnica in Reference to Determining the Legal Status of Jews, Former German Citizens in the Voivodeship of Lower Silesia), 30.07.1945, card 9. It is not known whether the author had the equality of Jews in mind, as declared in the decree of the Polish Committee of National Liberation, or a different document. 
The establishment of this inquiry was provoked by situations in which Jews of non-Polish origin demanded or applied for allocation of a shop or another business thus raising the starost's concerns. Especially when he was not sure about "their loyalty during the war"70. The official's problems might have seemed rather insignificant according to the report prepared by the CCJP representatives during the visit to Lower Silesia. In this document, Jewish activists claimed just and equal treatment for Jewish people, including assistance in obtaining flats and places of work. Generally speaking, they asked for every possible assistance - also of material character, and facilitation of Jewish committees' work ${ }^{71}$. The letter was written in response to animosity and signs of hostility towards the Jewish population. Obviously, this report did not take into account certain specific situations and the reality, including the existence of German Jews committees. Several weeks later, as early as October 1945, Jelenia Góra starost addressed another letter to the voivode, this time asking him about issuing documents according to the voivode's circular from $4^{\text {th }}$ August $^{72}$. On the basis of this act, authorised representatives of a particular district were allowed to issue temporary certificates of protection provided by the Polish state to the persons to whom the document was issued. To many people, this was the first step on the way to a verification process or a broadly understood polonization ${ }^{73}$. In fact, this was all about differentiating German Jews from the rest of the German population, thus enabling them to function in similar conditions to the rest of the so-called Polish Jews. The letter in question was issued because of a remark made by an Office of Public Security official that half-Jews or quarter-Jews were not allowed to become members of the committees, "not mentioning Germans"74, as Poland did not respect the Nuremberg Laws; the officer, Baumgarten, thus was demanding that all the "Mischlings" be crossed off the lists of those registered, suspecting that Germans, who were to be displaced, might have been hiding in the institution. Having doubts about such behaviour on the part of security organs, Wojciech Tabaka asked the voivode directly:

71 Ibidem, Raport CKŻP do Pełnomocnika Rządu RP Dolnego Śląska Wojewody Ob. Piaskowskiego w Legnicy (CCJP Report to the Polish Republic Government Delegate of Lower Silesia, Voivode Piaskowski in Legnica), 19.07.1945, card 25.

72 Ibidem, Pismo Pełnomocnika Rządu RP na obwód nr 29 Jelenia Góra do Pełnomocnika Rządu RP na Okręg Administracyjny Dolnego Śląska w Legnicy (Letter from the Polish Republic Government Delegate for Jelenia Góra District 29 to the Polish Republic Government Delegate for the Administrative District of Lower Silesia in Legnica), 02.10.1945, card 27.

73 See: M. Iwanek, Rok 1945, [in:] Jelenia Góra. Zarys..., p. 227; for more about verification, see: G. Strauchold, Autochtoni polscy, niemieccy, czy....Od nacjonalizmu do komunizmu (1945-1949), Toruń 2001, p. 47-69.

74 The State Archives in Wrocław, The Voivodeship Office in Wrocław, Sprawy narodowości żydowskie (Jewish Nationality Issues), ref. no. VI/269, Pismo Pow. Urz. Bezp. Publ w Jeleniej Górze do Komitetu Żydowskiego w Jeleniej Górze (Letter from the Poviat Office of Public Security in Jelenia Góra to the Jewish Committee in Jelenia Góra), 15.09.1945, card 30 
[...] whether this committee may accept as its members or provide defence to Jews or persons persecuted by Nazism because of their Jewish origin and who are also German citizens and whether additional certificates providing defence should be issued to them ${ }^{75}$.

The starost suggested issuing certificates in accordance with earlier circulars and letters, which he considered as necessary. He had been issuing such documents himself. It is not known whether and in what way Tabaka's letters were answered. At the end of October, the voivode communicated these doubts to another body. This time he asked the CCJP if, according to the statute of this institution, German Jews were allowed to become members of committees. I could not reached the answer to this question ${ }^{76}$.

Undoubtedly, German Jews stayed in Jelenia Góra for the following months. Moreover, they were also members of the committee. The only document proving this is the register of children ${ }^{77}$. More than half of them had German-sounding names and surnames. In my view, they were German Jewish children, although this cannot be verified on the basis of the register compiled right after the war that contained only adult people. Quarterly certificates of the state protection for those documents' owners also prove the presence of German Jews. As one can see, the starost did not stop issuing them. What is more, he continued the procedure for almost one year ${ }^{78}$. An interesting example in this context is the case of Augusta Sara Thiel, who was living in nearby Szklarska Poręba. In a letter addressed to the Ministry of Public Administration, she described her situation - that of a German Jewish woman protected by the state and despite this very fact dispossessed of her house. Beginning from July 1945, Thiel had important and successively renewed documents - an attachment to the letter. However, in April 1946 she was evicted from the guest house she had run before 1937. The building had been occupied by Polish and Soviet officers "for military purposes", which in this case was only a pretext to move into a grand and well-furnished house. In the document sent to the ministry, she wrote:

75 Ibidem, Pismo Pełnomocnika Rządu RP na obwód nr 29 Jelenia Góra do Pełnomocnika Rządu RP na Okreg Administracyjny Dolnego Ślaska w Legnicy (Letter from the Polish Republic Government Delegate for Jelenia Góra District 29 to the Polish Republic Government Delegate for the Administrative District of Lower Silesia in Legnica), 02.10.1945, card 27.

76 Ibidem, Pismo Pełnomocnika Rządu RP na Okręg Administracyjny Dolnego Śląska do CKŻP w Warszawie (Letter from the Polish Republic Government Deleagate for the Administrative District of Lower Silesia to the CCJP in Warsaw), 27.10.1945, card 33.

77 The Archives of the Jewish Historical Institute, CCJP Education Department, ref. no. 303/IX/1142, Jelenia Góra - Poviat Committee of Jews in Jelenia Góra. The lists of names of children, lists of food handed out 1946-1949. The register of children up to 14 years, 18.03.1946, card 2. In the document, 14 out of the 25 registered children have German-sounding names and surnames, e.g. Klaus Schlesinger, Heinz Hosenfeld, Hannelore Graf, Klaudia Schönnborn, etc. In the archive collections of the Jewish Historical Institute (materials of individual CCJP departments) there are no other documents describing German Jews in the city.

78 The State Archives in Wrocław, The Voivodeship Office in Wrocław, Sprawy narodowości żydowskiej (Jewish Nationality Issues), ref. no. VI/270, Zaświadczenie tymczasowe wydane przez Pełnomocnika Rządu RP na obwód nr 29 Jelenia Góra (Temporary certificate from the Polish Republic Government Delegate for Jelenia Góra District 29), 3.12.1945, card 38 
I am 72 years old and after hardships suffered in a concentration camp I am weak and ill. That is why I kindly and earnestly ask the Ministry to take care of my case so that the harm done to me may be compensated for and so that I might spend the rest of my elderly years in my own house and be able to run the guest house ${ }^{79}$.

The final outcome of Augusta Thiel's case is not known. Even though her letters reveal her determination to regain her property, the likelihood of the relocation of officers was probably rather small. In this period when property in the so-called Recovered Territories was generally reserved for settlers, the social status of Germans exceptionally low and the issue of German Jews unclear, the owner probably did not manage to return to the guest house. She was seeking to regain her property in a dynamic period of deporting German people from territories granted to Poland. In April and May transports with autochthones also departed from Jelenia Góra poviat ${ }^{80}$.

One year later, in July 1947, pursuant to instructions given by workers of the Socio-Political Department of the Voivodeship Office in Wrocław, the question of the number of German Jews in particular territories was directed to poviats. In the majority of poviats such communities were already non-existent. In total, according to the reports, in the voivodeship territory there were 135 Jews applying for leave to remain in Poland at that time. The greatest number, that is as many as 30 persons in Wrocław and 20 people, respectively, in Jelenia Góra poviat and Wałbrzych ${ }^{81}$. The rest were concentrated in only several neighbouring locations. It is not known if they managed to stay. It is probable that they left the region in the last transport going to Germany in the following year.

\section{Conclusion}

Jews who immediately after the end of the war found themselves in Jelenia Góra were an interesting community. Among its members, there were liberated camp prisoners, including also those from other countries; on the other hand, German Jews constituted the majority - those who had somehow survived the war period in the territory of their hometowns and surrounding areas. And it is on their initiative that in July 1945 a committee was formed that on the voivodeship scale was one of the first such structures. Despite the complicated political and social situation, the first transports of Polish settlers arriving in the city, Jews above all made efforts to organize their lives once again. It is understandable that they wanted to be treated

79 The State Archives in Wrocław, The Voivodeship Office in Wrocław, Sprawy narodowości żydowskiej (Jewish Nationality Issues), ref. no. VI/270, Pismo Augusty Sary Thiel do Ministerstwa Administracji Publicznej (Letter from Augusta Sara Thiel to the Ministry of Public Administration), 16.07.1946, card 39.

80 In 1946, more than 57,000 people left an assembly point in Jelenia Góra for the British zone alone see: B. Nitschke-Szram, Wysiedlenie ludności niemieckiej z Polski w latach 1945-1949, Zielona Góra 1999, p. 182.

81 The State Archives in Wrocław, The Voivodeship Office in Wrocław, Sprawy Żydów niemieckich starających się o pobyt na Z.O. 1947 r. (The Issue of German Jews Applying to Remain in the Recovered Territories 1947), ref. no. VI/270, Collective record sheet, July 1947, cards 2-3. 
equally with other Jews, as the system's victims, not like the rest of the Germans. Undoubtedly, their efforts corresponded with the postulates and promises given by clerks and individual officials, politicians - these were not completely executed though. In a dynamically changing situation, also in view of the growing number of new legal documents, the status of German Jews was unclear. Even if, as in the case of Jelenia Góra, they possessed certificates and had the opportunity to applying for residence in the area, it is clear that the execution of this law, the reality of that time did not favour such an outcome.

Finally, analogically to the German population, these Jews left the city. Thus, their experience was doubly complicated. As victims of the Third Reich, isolated for years from the rest of German society, in the end they had to leave their homeland together with other Germans and share the hardship of displacement - being in a way double victims of Hitler's politics ${ }^{82}$. In this context, an insoluble issue was their identification and the question of whether the Extermination experience emphasised their Jewish identity, in contrast to their prewar identification with Germanness, an example of which may be the case of Martin Sachs.

Yet another, equally important question is the issue of structural continuity. The committee established by German Jews shortly thereafter became an institution subordinate to the CCJP. For a short period of time, a Jewish population of two and even three different experiences and cultures participated in Jewish life in the city - German Jews, Polish Jews as well as those who had come from the USSR as part of the so called repatriation ${ }^{83}$ from the first half of 1946. And the latter, the most numerous group in the following years, continued both the work of Jewish institutions and the subsequent history of the Jewish community. Ultimately, the final experience of every single group was the same - migration. German Jews left together with other Germans as part of the deportation campaign, whereas Polish Jews in fear of danger caused by the atmosphere after the Kielce Pogrom left in 1946, and others just after the establishment of the state of Israel in the years 1948-1949 or simply as a result of the Jewish community disappearing in a city or - broadly speaking - in Poland ${ }^{84}$. It might be that time spent in camps for displaced persons (DP camps) in Germany, Aliyah for those leaving for Palestine or later to Israel or co-creating the Jewish community in one of the Western European countries represented their subsequent very similar experiences. Considerations of that kind need another, detailed research project on the basis of at least oral history.

82 Geschichte der Juden in Deutschland von 1945 bis zur Gegenwart, ed. by M. Brenner, München 2012, p. 127.

83 Some of those people were not speaking good Polish. At least for that reason a need for the establishment of Jewish school appeared. Children speaking only Russian language would have the opportunity of learning Polish language there. 


\section{Bibliography}

Berendt G., Emigracja ludności żydowskiej z Polski w latach 1945-1967, [in:] „Polska 1944/45-1989. Studia i Materiały", Vol. 7 (2006), p. 25-60.

Berendt G., Życie żydowskie w Polsce w latach 1950-1956. Z dziejów Towarzystwa Społeczno-Kulturalnego Żydów w Polsce, Gdańsk 2006.

Berendt G., Żydzi na gdańskim rozdrożu (1945-1959), Gdańsk 2000.

Borkowski M., Kirmiel A., Włodarczyk T., Śladami Żydów: Dolny Śląsk, Opolszczyzna, Ziemia Lubuska, Warszawa 2008.

Brenner M., German-Jewish history in modern times, vol. 2: Emancipation and acculturation: 1780-1871, New York 1997.

Brenner M., Nach dem Holocaust. Juden in Deutschland 1945-1950, München 1995.

Bronsztejn S., Uwagi o ludności żydowskiej na Dolnym Ślqsku w pierwszych latach po wyzwoleniu, „Biuletyn ŻIH”, No. 75 (1970), p. 31-54.

Bronsztejn S., Z dziejów ludności żydowskiej na Dolnym Ślqsku po II wojnie światowej, Wrocław 1993.

Cała A., Ochrona bezpieczeństwa fizycznego Żydów w Polsce powojennej: komisje specjalne przy Centralnym Komitecie Żydów w Polsce, Warszawa 2014.

Cohn W., Żadnego prawa - nigdzie: dziennik z Breslau 1933-1941. Wybrane fragmenty, ed. by N. Conrads, Wrocław 2010.

Datner-Śpiewak H., Po Zagładzie: społeczna historia domów dziecka, szkół, kół studentów w dokumentach Centralnego Komitetu Żydów w Polsce, Warszawa 2016.

Friedla K., Juden in Breslau/Wrocław 1933-1949: Überlebensstrategien, Selbstbehauptung und Verfolgungserfahrungen, Köln 2015.

Geschichte der Juden in Deutschland von 1945 bis zur Gegenwart, ed. by M. Brenner, München 2012.

Goldsztejn A., Powstanie skupiska ludności żydowskiej na Dolnym Śląsku w latach 1945-1947, „Śląski Kwartalnik Historyczny Sobótka”, Vol. 22 (1967), no. 1-2, p. 191-202.

Grabski A., Centralny Komitet Żydów w Polsce (1944-1950). Historia polityczna, Warszawa 2015.

Grabski A., Działalność komunistów wśród Żydów w Polsce: 1944-1949, Warszawa 2004.

Grabski A., Żydowski ruch kombatancki w Polsce w latach 1944-1949, Warszawa 2002.

Hirsch H., Gehen oder bleiben? Juden in Pommern und Niederschlesien 1945-1957, Göttingen 2011.

Iwanek M., Rok 1945, [in:] Jelenia Góra. Zarys rozwoju miasta, ed. by Z. Kwaśny, Wrocław 1989, p. 213-231.

Jaworski W., Żydzi na Górnym Ślq̨sku w latach 1945-1970, Sosnowiec 2001.

Kendziorek P., Program i praktyka produktywizacji Żydów polskich w działalności CKŻP, Warszawa 2016.

Kersten K., Polacy, Żydzi, komunizm. Anatomia półprawd 1939-68, Warszawa 1992.

Kobielec A., Filie obozu koncentracyjnego Gross-Rosen. Informator, Wałbrzych 2008.

Kobielec A., Więźniowie Żydzi w KL Gross-Rosen. Stan Badań, Wałbrzych 1993.

Konieczny A., Ewakuacja obozu koncentracyjnego Gross-Rosen w 1945 r., „Studia nad Faszyzmem i Zbrodniami Hitlerowskimi", Vol. 2 (1975), p. 163-189.

Konieczny A., The „Schmelt organisation” in Silesia, [in:] Jews in Silesia, ed. by M. Wodziński, J. Spyra, Kraków 2001, p. 173-179. 
Krasucki E., Historia kręci Drejdlem: z dziejów (nie tylko) szczecińskich Żydów, Łódź 2018.

Kwaśny Z., Na nowej drodze rozwoju (do I wojny światowej), [in:] Jelenia Góra. Zarys rozwoju miasta, ed. by Z. Kwaśny, Wrocław 1989, p. 132-150.

Kwiek J., Żydzi, Łemkowie, Słowacy w województwie krakowskim w latach 1945-1949/50, Kraków 2002.

Melchior M., Społeczna tożsamośćjednostki: wświetle wywiadów z Polakami pochodzenia żydowskiego urodzonymi w latach 1944-1955, Warszawa 1990.

Melchior M., Zagłada a tożsamość: polscy Żydzi ocaleni „na aryjskich papierach”: analiza doświadczenia biograficznego, Warszawa 2004.

Mieczkowski J., Żydzi, Niemcy i Ukraińcy na Pomorzu Zachodnim w latach 1945-1956: liczba, położenie i działalność polityczna, Szczecin 1994.

Mothes H., Die Juden in Stadt ind Kreis Hirschberg i. Rsgb, typescript, Hirschberg 1938.

Nitschke-Szram B., Wysiedlenie ludności niemieckiej z Polski w latach 1945-1949, Zielona Góra 1999.

Nusech Pojln. Studia z dziejów kultury jidysz w powojennej Polsce, ed. by M. Ruta, Cracow-Budapest 2008.

Olejnik L., Społeczność żydowska w Łodzi w latach 1945-1950. Zarys problemu, „Acta Universitatis Lodziensis. Folia Historica", Vol. 60 (1997), p. 125-147.

Pęziński P., Na rozdrożu: młodzież żydowska w PRL 1956-1968, Warszawa 2014.

Ruchniewicz M., Ruchniewicz K., Das neue jüdische Leben in Polen - Juden in Niederschlesien nach 1945, [in:] Jüdisches Leben zwischen Ost und West. Neue Beiträge zur jüdischen Geschichte in Schlesien, ed. by A. Herzig, K. Ruchniewicz, A. Brämer, Göttingen 2014, p. 473-502.

Ruta M., Bez Żydów? literatura jidysz w PRL o Zagładzie, Polsce i komunizmie, Cracow-Budapest 2012.

Rykała A., Rozmieszczenie Żydów w Polsce po drugiej wojnie światowej (1945-1950), „Rocznik Łódzki”, Vol. 48 (2001), p. 149-174.

Rykała A., Kulesza M., W kwestii skupisk ludności żydowskiej na Ślq̨sku w pierwszych latach po II wojnie światowej, „Studia Śląskie”, Vol. 61 (2002), p. 235-254.

Sadowski M., Deportacje niemieckich Żydów z Wrocławia do KZ-Theresienstadt $w$ styczniu i kwietniu 1944 r., „Studia nad Faszyzmem i Zbrodniami Hitlerowskimi”, Vol. 18 (1995), p. 261-270.

Sadowski M., Z badań nad więźniami żydowskimi wyzwolonymi w filiach obozu koncentracyjnego Gross-Rosen, „Studia nad faszyzmem i zbrodniami hitlerowskimi”, Vol. 16 (1993), p. 251-276.

Społeczność żydowska i niemiecka w Łodzi po 1945 roku, ed. by A. Lech, K. Radziszewska, A. Rykała, Łódź 2010.

Społeczność żydowska w PRL przed kampaniq antysemickq lat 1967-1968 i po niej, ed. by G. Berendt, Warszawa 2009.

Starnawski M., Socjalizacja i tożsamość żydowska w Polsce powojennej: narracje emigrantów z pokolenia marca '68, Wrocław 2016.

Strauchold G., Autochtoni polscy, niemieccy, czy... Od nacjonalizmu do komunizmu (1945-1949), Toruń 2001.

Szajda M., Poczq̨tki instytucjonalnego życia żydowskiego na Dolnym Ślq̨sku od maja do sierpnia 1945 roku, [in:] Koniec wojny na Ślqsku. Rok 1945. Studia i materiały, ed. by K. Jasiak, K. Kawalec, P. Stanek, Wrocław-Opole-Warszawa 2018, p. 169-177.

Szaynok B., Ludność żydowska na Dolnym Ślq̨sku 1945-1950, Wrocław 2000.

Szaynok B., Z historiq i Moskwq w tle: Polska a Izrael 1944-1968, Warszawa-Wrocław 2007. 
Szaynok B., Kersten K., Pogrom Żydów w Kielcach 4 lipca 1946, Warszawa 1992.

Tomkiewicz R., Komitet Żydowski w Olsztynie (1946-1949), „Rocznik Ziem Zachodnich”, Vol. 1 (2017), p. 123-142.

Waszkiewicz E., Kongregacja Wyznania Mojżeszowego na Dolnym Ślq̨sku na tle polityki wyznaniowej Polskiej Rzeczypospolitej Ludowej 1945-1968, Wrocław 1999.

Wieczorek P., Żydzi w Wałbrzychu i powiecie wałbrzyskim 1945-1968, Warszawa-Wrocław 2017.

Wolny M., Ludność żydowska w Świdnicy w latach 1945-1970, „Rocznik Świdnicki”, (2003), p. 128-157.

Ziątkowski L., Dzieje Żydów we Wrocławiu, Wrocław 2000.

Ziątkowski L., Między niemożliwym a koniecznym: reformy państwa pruskiego $w$ końcu XVIII i na poczq̨tku XIX wieku a proces równouprawnienia Żydów ze szczególnym uwzględnieniem sytuacji na Ślq̨sku, Wrocław 2007.

Żbikowski A., Sq̨d Społeczny przy CKŻP: wojenne rozliczenia społeczności żydowskiej w Polsce, Warszawa 2014

Żółkiewska-Rejak A., Zerwana przeszłość: powojenne środowisko żydowskiej inteligencji twórczej: pomoc materialna i organizacyjna ze strony CKŻP, Warszawa 2017. 
Marek Szajda

\section{German Jews in Jelenia Góra immediately After the End of the Second World War}

Abstract: This article presents the history of German Jews, survivors of the Extermination period, in Jelenia Góra in the years 1945-1947, that is from the establishment of the Jewish committee just after the end of the Second World War until the disappearance of this community two years later. This is the story of a group composed of people liberated from concentration camps as well as hiding in their homeland, including the "Mischling". In the text, different aspects of the functioning of the German Jewish population are discussed in the context of the influx of Polish Jews from the territories of central Poland and the USSR, their relations with the Central Committee of Jews in Poland and the Voivodeship (the term corresponding to 'province' in many countries; translator's note) Jewish Committee in Wrocław, as well as the state administration. The most interesting issue is the problem of the legal and social status of Jews who were striving to be recognised as victims of the Third Reich on equal terms with others, in this case most of all Polish Jews. Finally, almost all German Jews left the city during the deportation of the German population.

Keywords: German Jews, Jelenia Góra, Jewish committees, settlement, Western and Northern Territories 